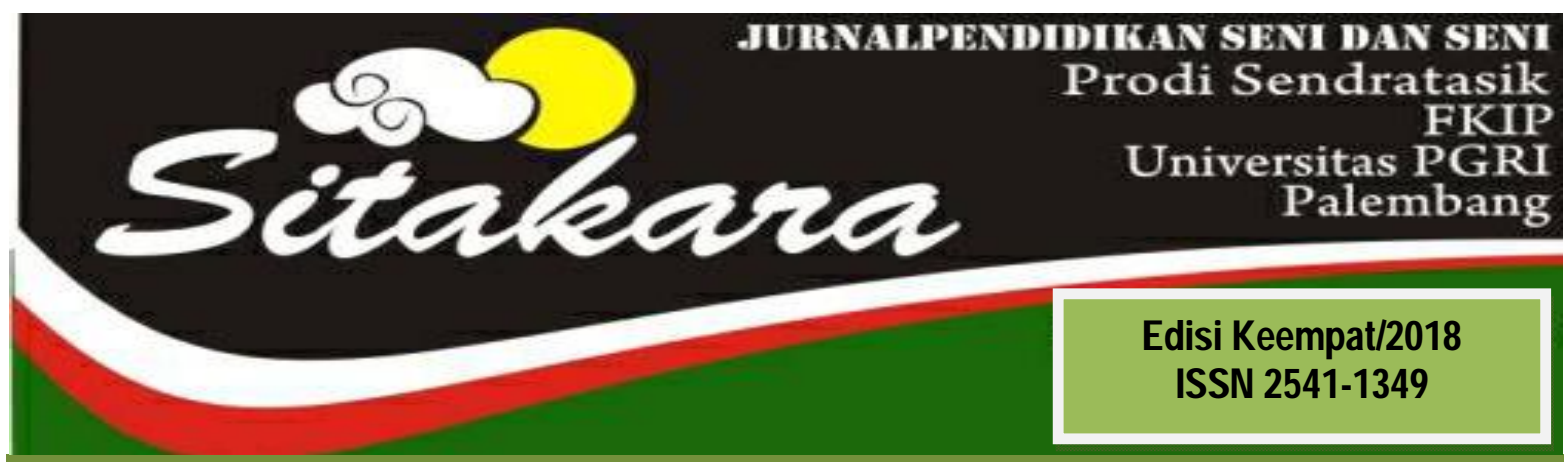

Objektifitas Imajinatif Dalam Pertunjukan Teater

Mohammad A rfani

Makna Estetis Dalam Simbol Tatto

Novdaly Fillamenta

Desain A tas (Air D esign) D alam Dimensi Estetik Pertunjukan Karya Tari

Efita Elvandari

Pengaruh M etode D emonstrasi D alam Pembelajaran Tari Burung Bermain

Pada Kegiatan Ekstrakurikuler D i SM P N egeri 36 Palembang

Ria Moulina A driamul

Gerak: Perjalanan D ari M otif Ke Komposisi Tari

Rully Rochayati

Sastra Lisan Dalam Kesenian Saluang D endang Sumatera Barat

Nofroza Yelli

Rangsang A udio Sebagai M otivasi Pada Penciptaan Karya

Tari Tunggu Tubang Dalam Pembelajaran Koreografi di Universitas

PG RI Palembang

Treny Hera

M otif Bungo Pacik Pada Tenunan Songket Palembang

Mainur

Konsep Kreatifitas Wallas D alam Proses Penciptaan Tari Tepak Keraton

Nurdin

A nalisis Bentuk Gerak Tari Turak Di Sanggar Studio Lingga

Kota Lubuklinggau

Sisca Fitriani

Bentuk Figur Tokoh Wayang Kulit Palembang

Robert Budi Laksana 


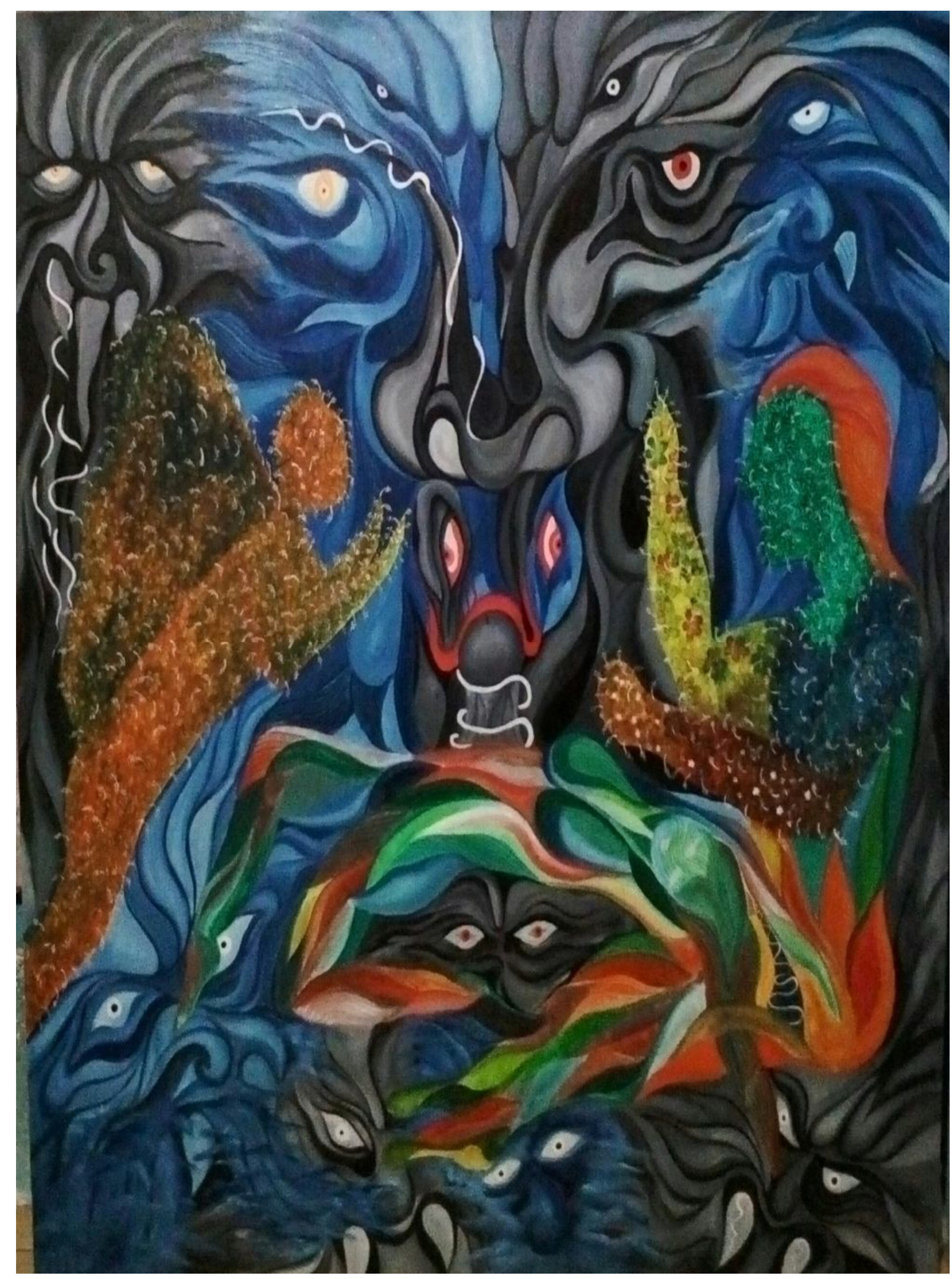




\section{SITAKARA}

\section{JURNAL PENDIDIKAN SENI DAN SENI BUDAYA}

Edisi 4, Februari 2018

\section{DEWAN REDAKSI}

1. PenanggungJawab

2. KetuaDewan Redaksi

3. WakilDewanRedaksi

4. Sekretaris

5. PenyuntingPelaksana

6. Penyunting Ahli

7. Setting
:

: Dra. Andinasari, M.M., M.Pd.

: RullyRochayati, M.Sn

: Nofroza Yelli, M.Sn

: Treny Hera, S.Pd., M.Sn

: 1. Efita Elvandari, M.Sn

2. Arfani, S.Pd., M.Sn

: 1. Prof. Dr. Triyono Bramantyo, P.Hd (ISI Yogyakarta)

2. Dr. DessyWardiah, M.Pd (UPGRI)

3. Dr. Slamet, M.Hum (ISI Surakarta)

4. Yayan Hariyansyah, M.Sn (UIGM)

: 1. Mainur, S.Pd.,M.Sn

2. I Komang Kerta Yana, S.Si

\section{AlamatRedaksi}

Program StudiPendidikanSendratasik JurusanPendidikanKesenian FKIP Universitas PGRI Palembang Jl. A. YaniLorongGotongRoyong 9/10 Ulu Palembang Telp. 0711-510043 Fax. 0711-514782 E-mail: jurnalsitakarasendratasik@yahoo.com 


\section{DAFTAR ISI}

Objektifitas Imajinatif D alam Pertunjukan Teater

M ohammad A rfani

Makna Estetis D alam Simbol Tatto

Novdaly Fillamenta

D esain A tas (Air D esign) D alam D imensi Estetik Pertunjukan Karya Tari

Efita Elvandari

Pengaruh M etode D emonstrasi D alam Pembelajaran Tari Burung Bermain 25 Pada Kegiatan Ekstrakurikuler Di SM P N egeri 36 Palembang

Ria M oulina Adriamul

G erak: Perjalanan D ari M otif Ke Komposisi Tari

Rully Rochayati

SastraL isanD al amK esenianSaluangD endang Sumatera Barat

N ofroza Yelli

Rangsang Audio Sebagai M otivasi Pada Penciptaan Karya

Tari Tunggu Tubang Dalam Pembelajaran Koreografi di Universitas

PG RI Palembang

Treny Hera

Motif Bungo Pacik Pada Tenunan Songket Palembang

Mainur

Konsep K reatifitas Wallas D alam Proses Penciptaan Tari Tepak Keraton N urdin

Analisis Bentuk G erak Tari Turak Di Sanggar Studio Lingga

Kota Lubuklinggau

Sisca Fitriani

BentukFigurT okohWayangKulit Palembang 


\title{
RANGSANG AUDIO SEBAGAI MOTIVASI PADA PENCIPTAAN KARYA TARI TUNGGU TUBANG DALAM PEMBELAJARAN KOREOGRAFI DI UNIVERSITAS PGRI PALEMBANG
}

\author{
Oleh : \\ Treny Hera \\ (Program Studi Pendidikan Sendratasik FKIP Universitas PGRI Palembang)
}

\begin{abstract}
ABSTRAK
Penelitian ini berjudul "Rangsang Audio Sebagai Motivasi Pada Penciptaan Karya Tari Tunggu Tubang Dalam Pembelajaran Koreografi Di Universitas PGRI Palembang" Penelitian ini bertujuan untuk mendeskripsikan penciptaan karya tari Tunggu Tubang dalam pembelajaran koreografi dengan rangsang audio sebagai motivasi dalam ide kreatif mahasiswa Jurusan Pendidikan Kesenian Universitas PGRI Palembang. Pendekatan yang dilakukan dalam penelitian ini adalah kualitatif dengan metode penelitian deskriptif. Data penelitian ini bersumber dari observasi partisipan dan proses pembelajaran pada mata kuliah Garap Sanggit Tari pada semester VII di Program Studi Pendidikan Sendratasik. Pengumpulan data yang digunakan melalui teknik observasi, wawancara serta dokumentasi pementasan karya tari hasil pembelajaran melalui ujian akhir semester. Hasil penelitian menunjukan bahwa rangsang audio menjadi motivasi pada penciptaan karya tari Tunggu Tubang yang merupakan tari tradisonal berakar dari tradisi masyarakat Semendo yang melestarikan kebiasaan turunan agar mematuhi kaidah-kaidah di dalam rumah sebagai saudara yang baik sesamanya. "Tunggu dapat diartikan menanti atau menunggu, sedangkan "Tubang" disebutkan tak lekang karena panas dan tak lapuk karena hujan.
\end{abstract}

\section{Kata Kunci: Rangsang Audio, Motivasi Belajar, Koreografi}

\section{A. PENDAHULUAN}

Pembelajaran koreografi merupakan suatu proses penciptaan karya tari yang mewadahi tahapan menata tari sampai terbentuknya karya tari yang siap disajikan untuk diapresiai oleh penonton. Dalam pembelajaran tersebut terjadi interaksi antar individu mahasiswa yang memposisikan dirinya menjadi seorang penata tari dengan keilmuan pendidikan seni tari sampai dengan terwujudnya karya tari yang utuh yang diawali oleh rangsang awal sebagai idesampai dengan tahapan evaluasi sebelum karya tari layak disajikan. Pembelajaran yang terjadi pada mahasiswa semester VII di Program Studi Pendidikan Sendratasik Universitas PGRI Palembang merupakan proses yang universal yang terjadi dilingkungan pendidikan dan setiap saat secara terus menerus. Proses pembelajaran khususnya pada penelitian ini pada penciptaan karya tari ditetapkan untuk memecahkan beragam masalah yang timbul dalam cara menata tari atau cara mengkoreograferi sebuah karya tari, yaitu diawali dengan ide sebagai modal utama mahasiswa dalam pembelajran tersebut. Karya tari merupakan hasil eksperesi, emosi, kegundahan, kekecewaan, kebahagian, fenomena kekinian yang dimiliki oleh pribadi 
mahasiswa sebagai pelaku, yang dituangkan melalui seni gerak yang ditata menjadi rangkaian gerak tari bermakna. Pembelajaran dan penciptaan karya tari harus diciptakan dan dirancang secara kreatif, yang memungkinkan terjadinya interaksi mandiri antara individu mahasiswa satu dengan mahasiswa lainnya. Dalam pembelajaran koreografi di Jurusan Pendidikan Kesenian dilakukan secara berkelompok untuk menumbuhkan jiwa kerja sama dan menciptaakan kondisi efektif dan efesien. Mata kuliah koreografi modal utamanya adalah mahasiswa harus memiliki ide kreatif dan berjiwa inovatif agar karya yang dihasillkan original dan menarik dengan mengangkat tradisi daerah masing-masing sebagai pelestarian budaya khususnya Sumatera Selatan. Berdasarkan pernyataan di atas masalah dalam penelitian sebagai berikut: 1) rangsang apa yang melandasi ide koregrafer sehingga menjadi motivasi dalam penataan karya tari Tunggu Tubang, 2) sumber apa saja yang dapat dijadikan koreografer sebagai rangsang awal dalam penataan karya tari Tunggu Tubang 3) proses dan tahapan penciptaan karya tari Tunggu Tubang. Pemilihan objek penelitian pada penciptaan karya tari Tunggu Tubang merupakan hal yang perlu dilakukan karena hasil penelitian dapat mengangkat tradisi turun temurun yang saat ini masih dilestarikan kepada pembaca agar menghargai dan mencintai tradisi di setiap daerah yang dimiliki walaupun ada beberapa kesenjangan pendapat dalam pelestraian tardisi tersebut.

\section{B. METODE PENELITIAN}

Penelitian ini bersifat deskriptif kualitatif, tujuannya adalah mendeskripsikan motivasi koreografer dalam mencipta karya seni dengan rangsang audio sebagai ide dan orientasi karyanya. Sesuai dengan bidang keahlian peneliti yaitu tari, maka bahasan dalam penelitian ini difokuskan pada ilmu tari, secara rinci metode yang digunakan adalah etnografi tari. Yaitu menjelaskan tentang tari serta elemen-elemen yang melingkupinya, juga dibahas tentang sisi kontekstual faktor pembentuk tari yang tidak terlepas dari kreativitas dan aktivitas senimannya. Penelitian model ini dapat dikatakan sebagai bentuk penelitian etnokoreologi, yang lebih menekankan pada tari sebagai subyek dan gender tari sebagai objeknya.

Metode kualitatif digunakan dalam penelitian rangsang audio sebagai motivasi pada penciptaan karya tari Tunggu Tubang dalam pembelajaran koreografi di Universitas PGRI Palembang. Secara tehnik pengumpulan data berupa data observasi, wawancara dengan mahasiswa semester VII jurusan pendidikan seni tari sebagai koreografer di Universitas PGRI Palembang dan nara sumber terkait sebagai pelestari tradisi Tunggu Tubang yaitu bapak Akhirtani, Ibu Sumarni, dan pemegang pewaris Tunggu Tubang yakni Asma Rida Wati.

\section{PEMBAHASAN}

Interpretasi seorang koreografer ikut mewarnai bentuk kemasan baru sajian tari. Menangkap esensi fenomena-fenomena penyajian seni tradisi menjadi awal rangsangannya. Salah satunya terangsang oleh gerak yang memiliki makna yang variatif. Proses kreatif mensyaratkan 
kreativitas sebagai dasar. Menurut Munandar (2012:25) kreativitas sebagai kemampuan umum untuk memberikan gagasan-gagasan baru yang dapat diterapkan dalam pemecahan masalah, atau sebagai kemampuan untuk melihat hubunganhubungan baru antara unsur-unsur yang sudah ada sebelumnya.

Ditinjau dari sisi kreativitas, sebenarnya setiap orang memilikinya. Hal yang membedakan manusia satu dengan manusia yang lain dari sisi kreativitas adalah dikembangkan atau tidaknya. Contoh sederhana bahwa suatu aktivitas baru disebut sebagai tontonan apabila ia dilakukan dengan kesengajaan dengan maksud untuk dilihat oleh orang lain untuk ditonton, seperti yang dikemukakan oleh Lois Ellfeldt dalam Munandar sebagai berikut:

Banyak sekali penari penari
merasa mapan bergerak
menginterpretasikan atau
mentafsirkan musik, apa lagi
kalau ia senang terhadap musik-
musik tertentu. Musik memiliki
medium dan bentuk ekspresinya
sendiri yang khas, musik
dikomposisikan untuk didengar.
Sebuah ekspresi yang lengkap
dan utuh dari nilai media yangh
lain. Dalam hal ini musik tidak
berfungsi sebagai pengiring tari,
tetapi lebih berarti sebaliknya,
tari yang mengiringi musik (Lois
Ellfeldt, 1977:36).

Sumber penciptaan merupakan gagasan yang melandasi terciptanya sebuah karya tari. Sumber penciptaan meliputi sumber garapan dan sumber ide/gagasan/tema. Penciptaan karya tari Tunggu Tubang pada mata kuliah koreografi dan garap sanggit tari diajarkan terlebih dahulu melalui sejumlah proses. Proses tersebut dikenal dengan tahapan produksi yang dimulai dengan tahap 1) Pengenalan ide penciptaan 2) Penyususnan Konsep 3) Penentuan Metode Penciptaan dan 4) Penulisan deskripsi penciptaan. Koreografer yang akan mengungkapkan ide estetiknya memilih dan menggarap beberapa medium terutama gerak untuk menciptakan suatu bentuk koreografi sebagai wadah ide menurut keahlian teknik dan selera (Tasman, 2006: 49). Kreativitas dan garap medium dalam pengungkapan rasa indah seorang koreografer biasanya ada pilihan pada bentuk koreografi, sebab pilihan bentuk koreografi dapat memberi arah dan tujuan pengungkapan dan makna estetik. Banyak cara dan teknik garap yang dilakukan seorang koreografer, di antaranya ada yang suka dengan bentuk verbal, tetapi juga banyak yang memilih gerak yang non verbal.

Rangsang tari merupakan suatu hal yang datang dari lingkungan yang dapat menyebabkan dan berpengaruh terhadapat bentuk gerak, gaya gerak, dan teknik gerak dalam tari.Jacqueline Smith (1985) menyebutkan istilah "rangsang tari" yaitu sesuatu yang membangkitkan fikiran atau semangat (kehendak) atau motivasi untuk beraktivitas (proses kreatif). Secara umum ada 2 jenis rangsang tari yaitu rangsang visual dan rangsang audio. 1) Rangsang visual ini menekankan pada semua jenis rangsang yang dapat dilihat, seperti melihat video, melihat gerakkarya tari, menirukan gerak, atau bahkan menstilisasi gerak. 2) Rangsang Audio ini menggunakan suara sebagai rangsangan. Suara 
tersebut dapat berupa teriakan, hentakan, pukulan pada perkusi, atau kaset yang berisi lagu-lagu.

\section{Pengenalan Ide Penciptaan}

Konsep penciptaan merupakan rancangan dari sebuah ide yang dinyatakan dalam sebuah kata atau simbol dari pengetahuan yang dimiliki seorang koreografer dari berbagai macam karakteristik untuk menjalankan proses mewujudkan gagasan dan ide kedalam sebuah karya. Tari mempunyai bagian pokok yaitu gerak, namun dalam perwujudannya tari tidak hanya menawarkan gerak-gerak saja tetapi terdiri dari aspek pendukung lainnya, antara lain :

\section{Rangsang tari}

Rangsang tari merupakan suatu hal yang datang dari lingkungan yang dapat menyebabkan dan berpengaruh terhadap bentuk gerak, gaya gerak, dan teknik gerak dalam tari. Jacqueline Smith (1985) menyebutkan istilah " Rangsang Tari " yaitu sesuatu yang membangkitkan fikiran atau semangat (kehendak) atau motivasi untuk beraktivitas (proses kreatif). Secara umum ada 2 jenis rangsang tari yaitu rangsang visual dan rangsang audio. 1) rangsang visual ini menekankan pada semua jenis rangsang yang dapat dilihat, seperti melihat video, melihat gerak karya tari, menirukan gerak, atau bahkan menstilisasi gerak. 2) rangsang audio ini menggunakan suara sebagai rangsangan. Suara tersebut dapat berupa teriakan, hentakan, pukulan pada perkusi, atau kaset yang berisi lagu-lagu.
Penciptaan karya tari Tunggu Tubang termotivasi oleh rangsang audio,berdasarkan cerita lisan yang dituturkan oleh koreografer bahwa didaerah Semende ( Muara Enim ) tentang adanya tradisi Tunggu Tubang. "Tunggu" dapat diartikan menanti atau menunggu, sedangkan "Tubang" disebutkan tak lekang karena panas dan tak lapuk karena hujan. Penyusunan sebuah koreografi diawali dasar pemikiran atau konsep garap yang dimiliki oleh seorang koreografer yang memiliki daya imajinasi dan kreatifitas yang inovatif. Suatu penciptaan sebuah karya tari dilandasi oleh beberapa hal:

1) Hal apa yang mendorong koreografer untuk menciptaakan koreografi? Hal yang mendorong koreografer tari Tunggu Tubang untuk meciptakan karya tersebut adalah melestarikan budaya Tungggu Tubang melalui pendokumentasian berupa karya tari disajikan kepada penonton yang mampu memberikan pengetahuan tentang adat Tunggu Tubang.

2) Kapan dorongan itu muncul dalam pikiran koreografer? Dorongan muncul dalam ide kreatif koreografer ketika dosen pengampu mata kuliah garap sanggit tari memotivasi mahasiswa untuk menggarap karya tari yang dilandasi dengan kisah nyata, fenomena kekinian dan kebudayaan setempat agar hasil karya tari benar orisinil bukan hanya tercipta atas daya khayal semata.

3) Bagaimana dorongan itu bisa terjadi? Dorongan tersebut bisa terjadi setelah koreografer memiliki keyakinan untuk menjadikan pengalaman hidup atau kisah 
nyata yang dialaminya sebagai pemegang dan penerus tradisi Tunggu Tubang.

4) Mengapa dorongan misalnya berupa ide gagasan sangat kuat dan membuat koreografer terkesan dengan hal tersebut? Hal yang memotivasi koreografer untuk menjadikan tradisi tersebut menjadi latar belakang penciptaan karya atas dasar keunikan tradisi yang dianut dan rasa menghargai budaya yang hidup dimasyarakt Semende.

5) Bagaimana dampak jika dorongan tersebut dituangkan dalam suatu gagasan dan ide penciptaan? Dampak daripada dorongan tersebut menjadi sebuah hal yang melatarbelakangi karya adalah tumbuhnya rasa menghargai sesama masyarakat Sumatera Selatan dan pendidik dalam budaya yang masing-masing memiliki tradisi untuk saling menghargai dan memahami sosiologi masyarakat setempat terhadapat terjaganya suatu tradisi.

6) Apa tujuan koreografer mengaplikasikan ide dan gagasan yang diperoleh ke dalam sebuah karya koreografi? Tujuan mengaplikasikan ide dan rangsang audio yang diperoleh untuk mengangkat kepermukaan masyarakat khususnya sumber daya di lingkungan Universitas PGRI Palembang untuk mengenal tradisi Tunggu Tubang di Semende dan menumbuhkan rasa menghargai serta menciptakan toleransi terhadapat adat istiadat yang memiliki nilai berbeda terhadap agama Islam.
Data hasil wawancara tersebut diperoleh berdasarkan pengumpulan data wawancara bersama koreografer ketika proses belajar mengajar dalam tahap landasan penciptaan.

Karya tari Tunggu Tubang berorientasi pada tradisi Tunggu Tubang di daerah Semende. Masyarakat Semende dikategorikan sebagai penganut prinsip kekerabatan matrilineo, berdasarkan tradisi Tunggu Tubang, anak perempuan paling tua menjadi pemegang hak pewaris. Harta warisan berupa rumah dan sawah yang tidak dibolehkan untuk dijual. Anak perempuan tertua mengacu ke anak perempuan pertama yang dilahirkan dalam keluarga. Artinya, bisa jadi anak perempuan tertua itu dalam urutan keluarga memiliki kakak laki-laki. Tradisi yang telah berjalan selama ratusan tahun itu, bertujuan untuk memastikan bahwa harta keluarga berupa rumah dan sawah tetap bisa dimanfaatkan oleh seluruh anggota keluarga (jurai dalam bahasa daerah Semende adalah keturunan). Tradisi ini agaknya didasarkan pada filosofi bahwa perempuanlah yang melahirkan kehidupan dan berasal dari rahim, maka perempun pula yang dipercaya untuk memeliharanya. Objek pelestari tradisi Tunggu Tubang dalam penelitian ini pada Keluarga Bapak Akhirtani dan Ibu Sumarni. Pada konteksnya yang menjadi pewaris keluarga adalah saudara perempuan tertua yaitu Asma Ridawati dan saudaranya bernama Dwi Raudatusaleha.

Rangsang awal pada tahap pencarian ide kreatif oleh mahasiswa Jurusan pendidikan tari di Universitas PGRI Palembang dengan karya tari Tunggu Tubang motivasi rangsangan yang 
digunakan adalah rangsang Audio. Tunggu Tubang adalah nama jabatan yang dipercayakan kepada anak perempuan tertua dalam suatu keluarga, dimana jabatan tersebut adalah merupakan jabatan otomatis yang sifatnya turun temurun dan biasanya jabatan tersebut diadakan penyerahan setelah anak perempuan tertua menginjak berumah tangga, namun dalam hal ini orang tua dari anak tersebut dapat hidup mandiri dalam keluarga sebagaimana layaknya anak-anak Tunggu Tubang yang lainnya dalam hidup berumah tangga.

Karya ini berdasarkan tradisi di daerah Semende Darat Ulu (Muara Enim). Dorongan ini muncul saat salah satu koreografer bercerita tentang tradisi di daerahnya bahwa anak perempuan tertua di daerah tersebut menjadi pewaris harta kedua orang tuannya. Dorongan itu bisa terjadi ketika kami mewawancarai salah satu lembaga adat yang ada di desa salah satu koreografer, "menurut bapak Idham" mengatakan bahwa tradisi Tunggu Tubang ini masih dilestarikan hingga sekarang. karya ini dibuat karena ketertarikan koreografer terhadap cerita tentang tradisi Tunggu Tubang (wawancara bersama Raudatusaleha). Walaupun di dalam pandangan hukum ahli waris pada agama Islam. berdasarkan Al-Quran (QS. An-Nisa: 176), anak laki-laki mendapat bagian harta lebih banyak dari anak perempuan. Pewarisan Tunggu Tubang di Semende yang diutamakan adalah anak perempuan. Bagian anak perempuan tertua lebih banyak dari pada anak laki-laki. Tradisi tersebut tetap diindahkan untuk menjaga nilai budaya di dalam pelestariannya.
Konsep penciptaan karya tari Tunggu Tubang disusun menjadi beberapa adegan:

a) Adegan $1:$ menunjukkan adanya ikatan persaudaraan antara Tunggu Tubang dan saudara-saudaranya.

b) Adegan 2 : timbulnya rasa iri saudarasaudara kepada Tunggu Tubang sehingga membuat Tunggu Tubang tersiksa

c) Adegan 3 : menunjukkan konflik antara Tunggu Tubang dan saudara-saudaranya

d) Adegan 4 : timbulnya rasa sadar saudarasaudara dari Tunggu Tubang bahwa warisan tersebut hanya jatuh kepada anak pertama yang disebut Tunggu Tubang.

Berikut hasil penelitian unsur pendukung karya tari Tunggu Tubang meliputi tema tari, gerak tari, mode penyajian, penari, busana, musik, dan properti:

Tari Tunggu Tubang ini mengangkat tema dramatik. Berawal dari kecemburuan saudara-saudara Tunggu Tubang atas harta wariasan yang didapatkan Tunggu Tubang.

Tari dramatik mengadung arti bahwa gagasan yang hendak dikomunikasikan sangat kuat dan penuh daya pikat (menarik), dinamis dan banyak ketegangan. Tari dramatik mungkin menekankan pada konflik antara seseorang dengan seseorang yang lain, atau konflik dalam dirinya sendiri. Tari dramatik memusatkan pada sebuah kejadian atau suasana dengan tidak keluar dari cerita.

Mode penyajian karya tari Tunggu Tubang adalah suatu bentuk hasil proses pengarapan yang mengantarkan pada suatu koeografi tertentu 
sehingga pada akhir proses garapan, seorang koreografer dapat memahami dengan benar bentuk koreografer yang telah diproduksi. Mode penyajian dalam hal ini adalah cara koreografer menyampaikan isi tari. Suatu penyajian koreografi lewat mode penyajian akan memberikan makna keindahan dalam primernya dari sikap jiwa, respon penonton, nilai rasa batin yang di tangkap oleh penonton, dan menimbulkan pengalaman bahkan kenangan yang ada. Ada dua mode penyajian karya yaitu : mode penyajian representasional dan mode penyajian simbolis (mode penyajian yang tidak menekankan obyek secara nyata, wujud penampilan tarinya adalah abstrak).

Tari Tunggu Tubang menggunakan mode penyajian representasional yang mengetengahkan wujud ide dari obyek secara nyata, segala gambaran-gambaran dalam karya akan benar-benar Nampak secara orisinil.

Penari adalah pelaku tari yang mengaudioisasikan gerakan tubuhnya (anggota badan) kedalam suatu tarian. Penari adalah seseorang yang menyajikan sebuah keindahan gerak tubuhnya dengan melibatkan daya tafsir dari ide estetik pada sebuah koreografi maupun imajinnya (Tasman,2006:7). Penari adalah individu yang menggunakan bakat mereka untuk mengkspresikan ide-ide emosi, cerita, dan bahkan suara dengan memanipulasi daerah tertentu dari tubuh. Daerah ini termasuk kepala, lengan, tangan, dada, pinggul, kaki, dan jari kaki.

\section{Penari dalam tari Tunggu Tubang} bejumlah empat orang, satu orang penari menjadi Tunggu Tubang yang memiliki karakter baik dan tiga orang penarinya yang menjadi saudara dari Tunggu Tubang memiliki karakter jahat atau iri terhadap Tunggu Tubang.

Gerak adalah bahasa tubuh yang melibatkan unsur anggota badan manusia sebagai media komunikasi yang memiliki makna atau tujuan tertentu. Gerak tari merupakan unsur utama dan merupakan gerakan yang indah. Gerak di dalam tari bukanlah gerak yang realities, melainkan gerak yang telah diberi sentuhan bentuk eskpresif dan nilai ekstesis.

Dalam tari Tunggu Tubang menggunakan berbagai desain gerak yang biasa digunakan pada tarian tradisional Sumatera Selatan yang kami kembangkan menjadi tarian Tunggu Tubang, yang menggunakan desain tinggi, datar, horizontal, dan desain rendah.

Tata rias adalah membuat garis-garis diwajah sesuai dengan ide/konsep garapan. Penataan rias pada penyajian tari Tunggu Tubang ini menggunakan tata rias panggung.

Tata busana adalah sebuah kebutuhan sandang yang dikenakan pada tubuh penari di atas pentas ditata koreografer sesuai dengan peranan yang dibawakan. Busana yang digunakan penari Tunggu Tubang yaitu baju kebaya,kain,celana dan selendang sebagai busana tradisional masyarakat Semende.

Elemen dasar musik adalah nada, ritme, dan melodi, mungkin sebuah tarian yang diiringi tepuk tangan tetapi perlu diingat,bahwa tepuk tangan itu sendiri sudah mengandung ritme yang merupakan salah satu elemen dasar musik pengiring tari. Musik iringan adalah unur penunjang tari (Soedarsono,1978:26). 
Musik pengiring pada karya ini bertujuan untuk memperkuat karya tari, adapun dalam karya tari "Tunggu Tubang" menggunakan musik internal dan eksternal:

a. Musik internal adalah musik atau bunyibunyian yang baerasal dari anggota tubuh manusia (penari), misalnya tepuk tangan, petik jari, tepuk dada, siulan, hentakan kaki ketanah dan sebagainya. Seperti halnya musik internal pada karya tari Tunggu Tubang menggunakan lagu tembang "Tunggu Tubang" adapun tembang pada karya tari Tunggu Tubang yaitu :

tunggu tubang anak betine ... sianu anak betine...

badah bekumpul badah bekumpul ngah kebalikan ...

sianu ngah kebalikan ...

tunggu tubang memang mah dek mak ...

sianu memang mak dek mak ...

upat ngedawai pait gak masam tanggung kah gale...

sianu tanggung kah gale ...

\section{Arti dalam bahasa Indonesia:}

Tunggu Tubang anak perempuan

Dia anak perempuan

Tempat berkumpul tempat berkumpul

Tempat pulang

Anak perempuan

Dia anak perempuan

Tunggu Tubang memang lemak dan tidak

Perempuan lemak dan tidak

Omongan di belakang pahit

Dan masam ditanggungkan semua

Dia anak perempuan...

\section{Proses Garapan Karya Tari Tunggu Tubang}

Mewujudkan suatu bentuk seni apapun itu tidak dapat terlepas dari proses. Proses kreatif merupakan bagian dari pola tindak dan pola pikir dirasa sangat penting karena dengan adanya proses kreatif seorang pencipta seni dapat mengetahui apa yang akan dilakukan, sebelum, sedang, dan sesudah karya tersebut terbentuk.

Kreatifitas dalam berkarya adalah sesuatu yang mempunyai sifat berkembang dalam setiap pergantian ruang dan waktu, juga setiap pola pikir yang dimiliki oleh penciptanya. Perkembangan inilah yang mampu membentuk karya secara maksimal dan utuh. Begitupun dalam proses penciptaan seni maka tahapan yang selalu digunakan oleh pencipta seni adalah :

\section{1) Tahap Awal}

Konsep seni secara dasar melibatkan kehidupan manusia itu sendiri dari alam batin maupun alam lahir (Batin) bermula dari pengalaman tersebut maka seni menjadi bagian yang terpenting dalam diri manusia. Menurut Jakob Sumardjo (2000:3-4) dalam buku filsafat seni menjelaskan bahwa seni adalah sebuah lembaga kebenaran. Sebuah lembaga dimana manusia menyadari bahwa kebenaran tidak dapat ditemukan secara mutlak. Sebuah lembaga yang harus terus dicari dan dicapai secara sadar dan bijaksana.

Garapan tari ini terinspirasi ketika koreografer mendengar cerita dari salah satu teman sekoreografer bahwa didaerah Semende Darat Ulu Kabupaten Muara Enim ada tradisi adat istiadat turun temurun yang mana seorang anak perempuan tertua lebih berhak memiliki harta warisan orang tuannya yang disebut Tunggu Tubang, kemudian koreografer menuangkan 
dalam sebuah karya tari yang berjudul "Tunggu Tubang ".

\section{2) Tahap Eksplorasi dan Improvisasi}

Tahap ini merupakan tahap kedua setelah menentukan ide dasar dari sumber yang akan diwujudkan. Tahap ini dipandang sangat penting karena dengan melampaui tahapan ini seorang penata atau pencipta tari telah mencoba untuk mengembangkan kreativitasnya dalam mengolah bentuk-bentuk gerak sesuai dengan keinginan penciptanya maka dibutuhkan waktu untuk mengolah gerak dengan melakukan eksplorasi dan improvisasi.

Keberhasilan kerja kreatif seorang koreografer tergantung pada kemampuan daya khayalnya dalam mengejawantahkan pengalaman batin ke dalam gerak. Pengejawantahan dari perasaan dan khayalan ke dalam gerakan, substansi kualitatif adalah aspek yang paling eksensial dalam proses kreatif (Hawkins, 2003:59).

Dalam sebuah karya tari ini dimulai dengan tahap eksplorasi gerak dasar tari Tunggu Tubang yang memiliki pola gerak yang lembut, tegas serta memasukkan unsur gerak tari tradisi pada masyarakat Semende.

\section{3) Tahap Pengorganisasian Bentuk}

Pengorganisasian bentuk dapat dipahami bahwa berbagai motif gerak yang sudah terwujud disusun atau diorganisasikan dalam bentuk yang utuh sesuai dengan ide garap penciptanya. Dalam beberapa teori tari akan ditemukan penyampaianpenyampaian yang berbeda namun pada dasarnya sama dalam penerapannya. Ketika pembahasan teori pengorganisasian bentuk maka dapat dipilih teori yaitu secara bentuk atau motif gerak, proses pembentukan melibatkan aspek-aspek komposisi yang dalam hal ini terkait dengan beberapa prinsip yang antara lain pengulangan, variasi dan kontras, transisi, penonjolan, dan rangkaian, (Smith.1981:68).

a) Pengulangan

Pengulangan sebagai bagian dari elemen konstruksi dalam teori Smith (terj.1985:4041) mempertegas bahwa kata "pengulangan" berarti sesuatu yang persis sama lagi

b) Variasi dan kontras

Variasi sangat dibutuhkan dalam gerak tari yang memacu tumbuhnya perkembangan gerak yang semakin menarik.

c) Transisi

Penata tari harus menggunakan unsur kontruksiyang biasa disebut dengan istilah transisi untuk menyambung seluruh bagian-bagian sehingga secara efektif mencipatakan keutuhan keseluruhan.

d) Klimaks atau Penonjolan

Klimaks dapat dilihat sebagai akhir pengembangan motif. Disegala kejadian, bila betul-betul mengiginkan untuk mencapai klimaks, maka klimaks harus tampak menonjol.

e) Rangkaian

Rangkaian atau sering disebut kontinyuinitas dari suatu kejadian juga terdapat di dalam koreografi atau bentuk 
tari, karena tari dapat dirasakan sebagai suatu pengalaman.

Motif pengembangan yang telah didapat dan dihapalkan, serta dipelajari secara berulang-ulang oleh koreografer untuk diberikan kepada penarinya. Gunanya agar penari bisa ikut merasakan pada setiap motif gerak yang telah diberi oleh koreografernya. Maka dari itu sangat perlu bagi koreografer untuk melatih penarinya agar bukan hanya bergerak saja tetapi juga membutuhkan strategi untuk mengelola kemampuan yang dimiliki oleh penari.

\section{4) Tahap Latihan}

Tahap latihan yang digunakan adalah :

Latihan dengan penari, proses latihan yang memakan waktu kurang lebih beberapa minggu dimanfaatkan semaksimal mungkin untuk beberapa langkah yaitu:

\section{a) Penyampaian Materi Dan Pola Lantai}

Materi gerak yang telah diperoleh diberikan kepada penari untuk dihapalkan sekaligus dengan pola lantainya. $\mathrm{Hal}$ ini dimaksudkan agar apa yang telah didapat segera diketahui atau dimengerti maksud gerak dan pola lantainya. Unuk itu latihan dengan penari terbagi dalam tiap-tiap adegan dengan harapan dapat diketahui kekurangan baik teknik gerak, cara penyampaian dan kekuatan-kekuatan dari aspekaspek seperti ruang, waktu, dan tenaga.

b) Penyampaian materi dengan properti

$$
\text { Properti yang digunakan adalah }
$$
selendang, pada tahap latihan dengan selendang hal yang ingin dicapai adalah kerja sama antar penari dalam menggunakan selendang tersebut tanpa terganggu oleh berat yang dapat berpengaruh pada kualitas gerak, pengefektifan jarak antar penari sehingga tidak menimbulkan benturan, dan kemampuan dalam menjaga jarak antara tubuh penari dengan properti.

c) Pemantapan

Pemantapan dilakukan agar penari dapat menguasai gerak teknik dan rasa gerak yang ingin diwujudkan. Pemantapan ini dilakukan berulangulang agar dapat diketahui kekurangan baik dari segi penari, gerak, pola latai, sehingga masih memiliki waktu untuk membenahinya.

\section{5) Evaluasi}

Pada tahap evaluasi ini ada beberapa masukan dari dosen pembimbing selama proses koreografer berlangsung yaitu :

a. Penari : Selama proses bimbingan banyak sekali masukan yang diberikan oleh dosen pembimbing kepada penari yaitu penari harus lebih menyesuaikan ekspresi dengan karakter penari, gerakan-gerakan yang ditarikan harus lebih diperjelas, interaksi antar penari harus lebih disesuaikan, kekompakan dalam gerakan diselaraskan dengan iringan musik.

b. Pemusik : Selama proses bimbingan masukan yang diberikan pada pemusik yaitu para pemusik harus memberikan sedikit tambahan pola musik sebelum perubahan gerakan, setiap alunan musik harus diperhalus agar sesuai dengan gerakan yang ditarikan oleh para penari. 


\section{SIMPULAN}

Rangsang auditif yang ditelaah oleh koreografer dalam hal ini adalah mahasiswa jurusan pendidikan seni tari di Universitas PGRI Palembang menjadiakan cerita lisan yang didengar hingga saat ini cerita tersebut memang nyata adanya di Desa Semendo bahkan salah satu koreografer meruapan salah satu keluarga yang melestarikan silsilah tradisi Tunggu Tubang. Objek pelestari tradisi Tunggu Tubang dalam penelitian ini pada Keluarga Bapak Akhirtani dan Ibu Sumarni. Pada konteksnya yang menjadi pewaris keluarga adalah saudara perempuan tertua yaitu Asma Ridawati dan saudaranya bernama Dwi Raudatusaleha.
Rangsang Audio menjadi motivasi dalam penciptaan karya seni tari Tunggu Tubang yang melekat pada tradisi di Semendo dan menyatu dengan kehidupan koreografer sendiri yang harus dibiasakan dalam kehidupan nyata kemudian diaplikasikan melalui media gerak tari sehingga terbentuk rangkaian gerak tari siap disajikan. Substansi karaya tari Tunggu Tubang dari hasil pembelajaran pendidikan di Universitas PGRI Palembang memberi warna dan variasi tari daerah dengan akar ide rangsan audio sebagai medianya.wujud karya tari tersebut merupakan wujud seni secara mandiri yang telah melalu tahapan koreografi pada proses pembelajaran di dalam kelas.

\section{DAFTAR PUSTAKA}

A.Tasman. 2008. Analisis Gerak dan Karakter. Surakarta: ISI Press Surakarta.

Munandar, Utami. Pengembangan Kreativitas Anak berbakat,Jakarta:Rineka Cipta, 2012.

Smith, Jacqueline. 1983. Komposisi Tari: Sebuah Petunjuk Praktis Bagi Guru, Terjemahan Ben Suharto, Yogyakarta: Ikalasti.

Soedarsono, R.M. 1999. Metodologi Penelitian Seni Pertunjukan dan Seni Rupa. Bandung: MSPI.

Sumardjo, Jacob. Filsafat Seni, Badung: ITB Press, 2000.

Waridi. 2005. Seni Pertunjukan Indonesia.Pasca Sarjana: STSI Surakarta.

DAFTAR NARA SUMBER 


\section{KETENTUAN PENULISAN ARTIKEL JURNAL SITAKARA}

1. Naskah berbahasa Indonesia bertemakan Seni Budaya yang meliputi hasil penelitian pengajaran seni budaya, cabang seni, dan kebudayaan.

2. Naskah harus asli dan belum pernah dimuat dalam media lain. Naskah dapat berupa hasil penelitian perorangan atau kelompok. Naskah ditulis dengan cara-cara yang sesuai dengan ketentuan penulisan artikel ilmiah menggunakan bahasa Indonesia yang baku, berupa ketikan, beserta soft line dalam CD-RW atau dengan mengirimkan email pada redaksi Jurnal Sitakara dengan alamat email: jurnalsitakarasendratasik@yahoo.com, spasi 1,5 jenis huruf Arrial Narrow ukuran 12, dengan panjang naskah antara 8-15 halaman pada kertas A4.

3. Artikel hasil penelitian memuat:

JUDUL

NAMA PENULIS

ABSTRAK

\section{A. PENDAHULUAN}

B. METODE PENELITIAN

C. HASIL DAN PEMBAHASAN

D. SIMPULAN

4. Artikel kajian konseptual memuat JUDUL

NAMA PENULIS

ABSTRAK

PENDAHULUAN

SUB JUDUL

SIMPULAN

DAFTAR PUSTAKA

\section{: XXX (HURUF KAPITAL)}

: (disertai jabatan dan institusi)

: (Bahasa Indonesia yang memuat 100- 150 kata diikuti kata kunci, dengan jenis huruf Arrial Narrow dan ukuran huruf 11 serta dicetak tebal).

: (Memuat latar belakang masalah, tinjauan pustaka Secara ringkas, masalah dan tujuan penelitian).

: (Berisi simpulan)

: XXX (HURUF KAPITAL)

: (disertai jabatan dan institusi)

: (Bahasa Indonesia yang memuat 100- 150 kata diikuti kata kunci, dengan jenis huruf Arrial Narrow dan ukuran huruf 11 serta dicetak miring)

: (Memuat latar belakang masalah, tinjauan pustaka secara ringkas, masalah penelitian dan tujuan penelitian)

: Sesuai dengan kebutuhan (tanpa numbering)

: (Berisi simpulan dan saran)

: (Berisi pustaka yang dirujuk dalam uraian naskah) 
5. Referensi sumber dalam teks artikel ditulis dengan menggunakan side note, contoh: (Jalalluddin, 1991:79); (Taufik, 2005;350); (Hamid dan Madjid, 2011:43). Sementara penulisan daftar pustaka disusun dengan ketentuan. Nama Pengarang. Tahun Terbit. Judul (dicetak miring). Kota Terbit: Nama Penerbit. Contoh: Koentjaraningrat. 2010. Manusia dan Kebudayaan Di Indonesia. Jakarta: Djambatan.

Daftar pustaka hanya memuat pustaka/sumber yang dirujuk dalam uraian dan disusun menurut abjad, tanpa nomor urut.

6. Naskah yang dimuat akan disunting kembali oleh redaksi tanpa mengubah isinya.

7. Naskah yang ditolak (tidak bisa dimuat) akan dikirim kembali ke penulis dengan pemberitahuan tertulis dari redaksi atau alamat email.

8. Penulis yang naskahnya dimuat akan mendapatkan 1 (satu) majalah nomor yang bersangkutan.

9. Contact Person: Treny (085357344704) dan Mainur (081373165553). 